desoxycholate $(10 \mathrm{ml}$. of $20 \%$ solution) which increases the emulsifying power of the blood and so reduces the size of circulating fat globules is limited because in larger doses it produces hæmolysis. Next, anticoagulant therapy has been advocated (Cobb and Hillman, 1961). Heparin is supposed to alter the lipoprotein density and would also prevent thrombosis if an occlusion did occur from the fat globules. From this small series, the impression gathered was that severe cases treated with anticoagulants recovered from the effects of fat embolism sooner than those treated without.

The treatment of these four cases has been discussed briefly; they are presented because they recovered in spite of prolonged unconsciousness, hyperpyrexia, respiratory and neurological involvement. It is also apparent that at the moment, beyond reduction of the hyperpyrexia, the quietening of the restlessness, and provision of a free airway for the patient with respiratory distress there is little to be done except to give anticoagulants, which did not interfere with fracture healing.
I wish to express my gratitude to Mr. R. C. Tatham and Mr. C. R. Berkin, Orthopædic Surgeons, for permission to publish these case histories of patients treated under their care and for the helpful advice given in the presentation of this article.

\section{REFERENCES}

Bailey, H. (1960): Signs and Symptoms in Clinical Surgery. p. 793. Bristol: John Wright.

BAILEY, H., and LOVE, M. (1960): A Short Practice of Surgery. p. 96, 11th edition. London: H. K. Lewis. CoBb, C. H. and Hillman, J. W. (1961): 'Fat Embolism' Instructional Course Lectures, 1961 (Fred Reynolds) p. 122. American Academy of Orthopædic Surgeons.

GARDNER, A. M. N. and HARRISON, M. H. M. (1957): Report of the Treatment of Fat Embolism with Heparin, J. Bone Jt. Surg., 39B, 538.

KeY, J. A. and CoNwell, H. E. (1956): Management of Fractures, Dislocations and Sprains. 6th edition. p. 125. London: Henry Kimpton.

Newman, P. H. (1948): Clinical Diagnosis of Fat Embolism. J. Bone Jt. Surg., 30B, 290.

Newman, P. H. (1962): Fat Embolism. ibid, 44B, 761. Peltier, L. F. (1956): Fat Embolism-The Prophylactic Value of a Tournique, ibid, 38A, 835.

Whitson, R. O. (1951): Critique of Fat Embolism, ibid, 33A, 447.

\title{
INTRACTABLE PRURITUS DUE TO HEPATIC CIRRHOSIS RELIEVED BY CHOLESTYRAMINE
}

\author{
Kalman KeCZKes*, M.B.Glas., M.R.C.P.E. \\ Registrar \\ Alan Lyell, M.D.Camb., F.R.C.P.E. \\ Physician-in-Charge
}

Department of Dermatology, Glasgow Royal Infirmary.
PruRitus due to liver disease is almost always due to biliary obstruction with associated retention of bile salts and other ingredients of the bile. The pruritus is always troublesome and its control is notoriously unsatisfactory. We report a case of hepatic cirrhosis whose pruritus was successfully relieved by cholestyramine.

\section{Case Report}

A married woman aged 47 attended the dermatological out-patient department on December 5th, 1962, complaining of severe generalised pruritus and tiredness for the last 5 years. At the beginning of her illness she had had bouts of violent sickness and vomiting at intervals of 6 to 7 months, but this had not troubled her much lately, although she had to avoid fried food because it made her feel sick.

She had scarlet fever in childhood. She had lived in N. Rhodesia from 1940 to 1946 where she suffered from enteritis and several mild attacks of malaria, from which she had been free since her return.

$$
\text { * Present Address: }
$$

Department of Dermatology, Dundee Royal Infirmary.
She was seen elsewhere for her skin complaint in 1960 and was put on Liq. Arsenicalis (Fowler's solution), which controlled her itching for the first time. She was kept on arsenic for about a year with reasonable control of pruritus, and thereafter this regime was stopped. Soon afterwards the pruritus returned, no other means could be found to control it, and it eventually got so bad that it interfered seriously with her sleep.

Physical examination revealed a thin, anxious looking woman with an earthy discolouration of the whole skin. There were numerous scratch marks on the body and limbs and some scattered superficial scars on the trunk and upper limbs. The provisional diagnosis was dermatitis herpetiformis and she was put on Dapsone $100 \mathrm{mg}$. b.d., which failed to control the pruritus. She was accordingly admitted on the 23rd April, 1963 for further investigation.

In hospital she was noticed to have pale coloured stools and dark urine occasionally, and her liver was palpable three finger breadths below the costal margin.

Investigations: $\mathrm{Hb} .11 \mathrm{gg} / 100 \mathrm{ml}$. PCV $35 \% \mathrm{MCHC}$ $32 \%$. The blood film was normal and Heinz bodies could not be found. Thrombotest $100 \%$. ESR 37 
mm./hour (Westergren). Serum proteins: total 5.3 g. $/ 100 \mathrm{ml}$., albumin $2.5 \mathrm{~g}$., globulin $2.8 \mathrm{~g} . / 100 \mathrm{ml}$. Thymol turbidity 3.6 units, alkaline phosphatase 43 K.A. units. Van den Bergh test: direct reaction positive. A cholecystogram showed normal filling, and no gallstones were visible. Clotting time 7 minutes. Bleeding time 65 seconds.

She was still thought to have dermatitis herpetiformis and the liver damage was provisionally attributed to the previous treatment with Liq. Arsenicalis. She was put on Cyproheptadine $4 \mathrm{mg}$. q.i.d. and discharged. The pruritus, however, failed to improve and she was readmitted on 10th September, 1963.

She described having had pale stools, flatulence and dark urine again, and we found a slight yellowish discolouration of the scleræ. Her itching was almost unbearable. The liver was as large as before, smooth and tender. The spleen was not palpable and there was no ascites. The skin was earthy brown over the whole body as before, there were numerous scratch marks, and on both upper limbs there were a few scattered erythemato-papular lesions.

Further Investigations: Bile was detected in the urine. ESR $37 \mathrm{~mm}$./hour (Westergren). Hb. 10.3 g. / 100 ml., PCV 37\%, MCHC 28\%. Film-"the red cells show hypochromia with marked anisocytosis. The white cell series is normal in type and distribution". Thrombotest $100 \%$. LE latex test negative, repeatedly. Serum proteins: total $6.9 \mathrm{~g} . / 100 \mathrm{ml}$., albumin 2.9 and globulin $4.0 \mathrm{~g} . / 100 \mathrm{ml}$. Thymol turbidity 3.6 units. Alkaline phosphatase 40.1 K.A. units. Electrophoresis showed a slight increase in the gamma globulin fraction. SGOT 71 units $/ \mathrm{ml}$. Van den Bergh test, direct reaction positive. Serum cholesterol $230 \mathrm{mg} . / 100 \mathrm{ml}$. Bromsulphthalein test showed impaired excretion of the dye $(30.5 \%$ remained). A 6-day fæcal collection showed high fạt excretion. Intravenous cholecystograph showed normally functioning gall bladder and no evidence of calculi. Skin biopsy, barium swallow and ECG showed no abnormality. Specimens of hair and nails submitted to activation analysis showed a normal arsenic content (hair 0.07 p.p.m.; nail 0.18 p.p.m.).

On October 11 th, 1963, a percutaneous liver biopsy was performed under local anæsthesia, which showed a cirrhotic process with alteration of the liver architecture. The spurs of connective tissue between the hepatic cells contained chronic inflammatory cells suggesting that the lesion was not completely quiescent, but there was no evidence in the specimen of an obstructive process. The histological picture was reported as consistent with cryptogenic cirrhosis (Fig. 1).

Treatment: On October 25th, 1963, she was put on cholestyramine $6 \mathrm{~g}$./day, in three divided doses, and ferrous gluconate $200 \mathrm{mg}$. t.i.d. Three days later the pruritus started to abate, and in a week it had completely disappeared. She was able to take the capsules easily and had no noticeable side effects. She never showed any bleeding tendency. The prothrombin time was checked on alternate days and found to be normal. Her bowel habits remained unchanged. She was discharged home on November 11 th to continue the treatment.

She has been followed up regularly as an outpatient. She has remained free of itching, has maintained her appetite and weight, and has never shown any tendency to bleed. Two months after the treatment began she developed slight looseness of the stools. She is still under observation. A

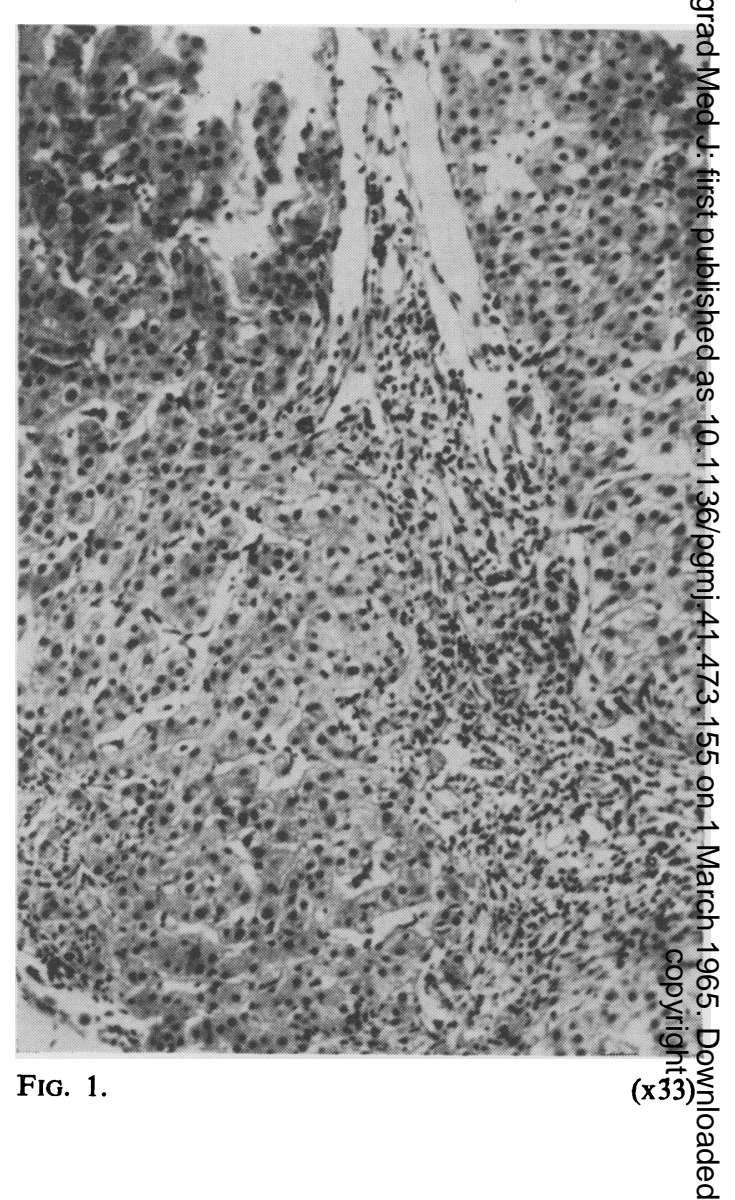

recent reduction of the dose to $4 \mathrm{~g}$./day was followe quickly by a slight recurrence of pruritus.

\section{Discussion}

Hepatic cirrhosis, especially biliary cirrhosis (or chronic intra-hepatic biliary obstruction, term preferred by Sherlock), is well known te have an insidious onset, as our case demonstrates

The intense pruritus, the skin lesions, and the fact that Liq. Arsenicalis brought relief suggeste裉 the diagnosis of dermatitis herpetiformis to begig with. She was therefore put on Dapsone and out failure to influence the pruritus with this drug led us to investigate the case further. The abnormal biochemical and hæmatological findings pointed to parenchymatous liver disease. The lack of evidence of extra-hepatic obstruction, the persistently high serum alkaline phosphatase, the behaviour of the serum proteins and bilirubie suggested biliary cirrhosis, but this diagnosis was not fully supported by the histological examination of the liver biopsy specimen, which showed hepatie? cirrhosis without the specific features of biliary cirrhosis. Since our patient has neither had overs infective hepatitis, nor homologous serum jaun dice, was not in the habit of taking alcohol an $\frac{\text { P }}{8}$ 
had adequate diet, we considered whether the arsenic, a known hepatotoxic agent, could have been the cause of her cirrhosis, since she had taken it for about a year. We feel, however, that the normal values for arsenic in hair and nails weigh against this possibility. The cause of the cirrhosis is uncertain but we feel that the insidious onset, the persistently raised alkaline phosphatase, the absence of hypertension and the behaviour of the serum proteins are all in favour of biliary cirrhosis. Whether she also has dermatitis herpetiformis is hard to tell, but it would be difficult to explain the response to arsenic without making this supplementary diagnosis. At no time since we have had her under observation has she had the typical eruption of dermatitis herpetiformis.

It is well known that biliary obstruction is often associated with pruritus. The exact cause of this is not understood, but it is suspected that the accumulation of bile acids could be responsible, although no correlation between the degree of bile acidæmia and the pruritus could be demonstrated (Osborn, Wootton, Da Silva and Sherlock, 1959).

Intermittent surgical drainage helps to relieve the pruritus of obstructive jaundice temporarily (Varco, 1947). Methyltestosterone (Lloyd-Thomas and Sherlock, 1952) and norethandrolone (Sherlock, 1959) are also effective, but they tend to deepen the jaundice in obstruction, and to cause bromsulphthalein retention in normal subjects, and hence their use is of doubtful value (Foss and Simpson, 1959).

An entirely new therapeutic approach was the introduction of cholestyramine, a strongly basic quaternary ammonium anion exchange resin, that forms insoluble compounds with bile acids in the gut which are neither digested nor absorbed (Tennent, Siegel, Zaretti, Kuron, Ott and Wolf, 1959). Hashim and Van Itallie (1960) successfully treated 4 cases of biliary cirrhosis. Itching disappeared within 2 weeks of starting cholestyramine $15 \mathrm{~g}$./day. Steatorrhoea, accompanying high doses of cholestyramine, was the only side-effect noted. Carey and Williams (1961) came to similar conclusions in treating 4 cases of chronic obstructive jaundice, and found that the resin was ineffective in complete obstruction. Datta and Sherlock (1963) treated 10 patients (9 with primary biliary cirrhosis and 1 with congenital atresia) with cholestyramine. They noted that the pruritus was relieved in 4 to 11 days after the administration of 6.6 to $10 \mathrm{~g}$. of cholestyramine daily. Bile acids usually fell and output of fæcal fat increased. Visintine, Michaels, Fukayama, Conklin and Kinsell (1961), treating a case of xanthomatous biliary cirrhosis with cholestyramine, noticed relief of the pruritus in one week.
These successes with cholestyramine led us to use it in our patient, in whom it proved very helpful.

\section{Summary}

A case of intractable pruritus is described, which proved to be due to hepatic cirrhosis. The pruritus has been successfully controlled by the continued administration of cholestyramine in a dose of $6 \mathrm{~g}$. daily. The literature on cholestyramine has been reviewed.

\section{Addendum}

The patient is still well controlled 14 months after starting treatment. She has needed vitamin $\mathrm{K}$ by injection.

Our grateful acknowledgements are due to Dr. G. Macdonald for carrying out the liver biopsy, to Mr. J. M. A. Lenihan the Regional Physicist for the activation analysis, to Mr. J. C. Towler for the photomicrographs, and to Mrs. M. Cusick for the secretarial work. We and the patient are specially indebted to Messrs. Merck, Sharp and Dohme Ltd., Hoddesdon, Hertfordshire, who, through Drs. J. F. Merry and F. G. Clayton provided, and are continuing to provide, the cholestyramine.

\section{REFERENCES}

Carey, J. B. Jr., and Williams, G. (1961): Relief of Pruritus of Jaundice with a Bile Acid Sequestring Resin, J. Amer. med. Ass., 176, 432.

DatTA, D. V., and SHERLOCK, S. (1963): Treatment of Pruritus of Obstructive Jaundice with Cholestyramine, Brit. med. J., i, 216.

FosS, G. L., and SimPSON, S. L. (1959): Oral Methyltestosterone in Jaundice, ibid, i, 259.

Hashim, S. A., and Van Itallie, T. B. (1960): Use of Bile Acid Sequestrant in Treatment of Pruritus Associated with Biliary Cirrhosis, J. invest Derm., 35, 253.

Hashim, S. A., Bergen, S. S. Jr., and Van Itallie, T. B. (1960): Steatorrhoea Induced in Man by Means of Bile Acid Sequestrants, Clin. Res., 8, 201.

LloYd-ThOMAS, H. G. L., and SHERLOCK, S. (1952): Testosterone Therapy for the Pruritus of Obstructive Jaundice, Brit. med. J., ii, 1289.

Osborn, E. C., Wootton, I. D. P., Da Silva, L. C., and SHerLoCK, S. (1959): Serum-Bile-Acid Levels in Liver Disease, Lancet, ii, 1049.

SHERLOCK, S. (1959): Primary Biliary Cirrhosis (Chronic Intrahepatic Jaundice), Gastroenterology, 37, 574.

TenNent, D. M., Siegel, H., Zaretti, M. E., Kuron, G. W., OTT, W. H., and WoLF, F. J. (1959): Reduction of Plasma Cholesterol in Animals with Bile Acid Sequestrant, Circulation, 20, 969.

VARCo, R. L. (1947): Intermittent External Biliary Drainage, for Relief of Pruritus in Certain Chronic Disorders of the Liver, J. Lab. clin. Med., 21, 43.

Visintine, R. E., Michaels, G. D., Fukayama, G., CONKLIN, J., and KINSELL, L. W. (1961): Xanthomatous Biliary Cirrhosis Treated with Cholestyramine, Lancet, ii, 341. 